Abstracta Iranica Abstracta Iranica

Revue bibliographique pour le domaine irano-aryen

Volume 27 | 2006

Comptes rendus des publications de 2004

Constitution de la République islamique d'Iran. Traduction, introduction et notes, Paris, Harmattan, 2004, 119 p.

Bernard Hourcade

(2) OpenEdition

Journals

Édition électronique

URL : http://journals.openedition.org/abstractairanica/6627

DOI : 10.4000/abstractairanica.6627

ISSN : 1961-960X

Éditeur :

CNRS (UMR 7528 Mondes iraniens et indiens), Éditions de l'IFRI

Édition imprimée

Date de publication : 15 mai 2006

ISSN : 0240-8910

Référence électronique

Bernard Hourcade, "Constitution de la République islamique d'Iran. Traduction, introduction et notes, Paris, Harmattan, 2004, 119 p. », Abstracta Iranica [En ligne], Volume 27 | 2006, document 361, mis en ligne le 02 janvier 2007, consulté le 25 septembre 2020. URL : http://journals.openedition.org/ abstractairanica/6627 ; DOI : https://doi.org/10.4000/abstractairanica.6627

Ce document a été généré automatiquement le 25 septembre 2020.

Tous droits réservés 


\section{Constitution de la République islamique d'Iran. Traduction, introduction et notes, Paris, Harmattan, 2004, 119 p.}

\section{Bernard Hourcade}

Cet ouvrage est un manuel indispensable. C'est la première traduction française du texte persan de la Constitution de la république islamique de 1979 révisée en 1989. Outre l'exactitude du vocabulaire et des notions, éclairées par des notes pour éclairer les ambiguïtés possibles du texte, cette traduction est complétée par une longue introduction qui met en évidence les grands principes constitutionnels, politiques et religieux et les évolutions historiques et politiques qui ont justifié la révision de 1989.

INDEX

Thèmes : 13.1. Iran

\section{AUTEURS}

BERNARD HOURCADE

CNRS - Paris 